\title{
Effect of oysters Crassostrea virginica and bottom shear velocity on benthic-pelagic coupling and estuarine water quality
}

\author{
Elka T. Porter ${ }^{1, *}$, Jeffrey C. Cornwell ${ }^{2}$, Lawrence P. Sanford ${ }^{2}$ \\ ${ }^{1}$ University of Maryland Center for Environmental Science, Chesapeake Biological Laboratory, 1 Williams Street, Solomons, \\ Maryland 20688, USA \\ ${ }^{2}$ University of Maryland Center for Environmental Science, Horn Point Laboratory, PO Box 775, Cambridge, \\ Maryland 21613, USA
}

\begin{abstract}
Increasing the biomass of bivalve suspensions feeders has been proposed as a means to improve water quality in eutrophic estuaries such as the Chesapeake Bay. However, water quality impacts are likely to be determined by the balance of bivalve feeding and the deposition and sediment regeneration of nutrients from particulate organic matter. In shallow-water environments, benthic and pelagic processes are closely coupled and water flow can regulate the supply of seston to the bivalves. In addition, such flow may regulate benthic-pelagic nutrient fluxes through mass transfer limitation and resuspension. We studied the interacting effects of juvenile oysters Crassostrea virginica and bottom shear velocity on phytoplankton biomass and on nutrient regeneration in a series of three $4 \mathrm{wk}$ long comparative experimental ecosystem experiments. All mesocosms had a $1000 \mathrm{l}$ water volume, a $1 \mathrm{~m}^{2}$ sediment surface area, and a $1 \mathrm{~m}$ water-column depth, and the same realistic water-column mixing (turbulence intensity $1 \mathrm{~cm} \mathrm{~s}^{-1}$ ). The systems included a multi-component mesocosm with moderate bottom shear velocity $\left(0.6 \mathrm{~cm} \mathrm{~s}^{-1}\right)$ and 2 standard cylindrical tanks with an unrealistically low bottom shear velocity $\left(0.1 \mathrm{~cm} \mathrm{~s}^{-1}\right)$. Oysters shifted processes to the sediments by decreasing phytoplankton biomass without stimulating additional blooms and by increasing light penetration to the bottom. Through complex and indirect relationships, the interaction of oysters and enhanced shear velocity significantly affected microphytobenthos biomass. Light, as enhanced by the oyster feeding on phytoplankton, increased microphytobenthos biomass; a moderate bottomshear velocity eroded the biomass. Microphytobenthos biomass decreased nutrient regeneration from the sediments to the water column and may have implications for water quality in low-energy parts of shallow-water estuaries such as Chesapeake Bay. Enhanced bottom shear in more energetic parts of shallow estuaries negatively affects microphytobenthos biomass and may increase nutrient regeneration from the sediments.
\end{abstract}

KEY WORDS: Benthic-pelagic coupling $\cdot$ Crassostrea virginica $\cdot$ Shear velocity $\cdot$ Microphytobenthos $\cdot$ Chesapeake Bay

Resale or republication not permitted without written consent of the publisher

\section{INTRODUCTION}

When the ratio of benthic surface area to water volume is high, such as in shallow-water ecosystems, benthic and water-column environments are closely coupled (Dame 1996). This coupling has been recognized for a relatively long time, and Verwey's (1952)
Wadden Sea study first identified the major role that bivalve suspension feeders play in pelagic-benthic coupling. Bivalve suspensions feeders facilitate the transfer of particles and nutrients from the water column to the sediments in the form of biodeposits (Jordan 1987, Bayne \& Hawkins 1992), and bivalves have been proposed as an additional method to reduce 
phytoplankton biomass (Dame et al. 1980). An increase in bivalve populations to historical population levels has been suggested as a method to bring ecosystems back to their natural balance and to improve water quality (Cloern 1982, Officer et al. 1982, Cohen et al. 1984, Newell 1988).

The euryhaline, epibenthic, bivalve suspension feeder Crassostrea virginica (Gmelin) has been thought to be a keystone species for one of the 'largest estuaries of the world' (Kennedy 1996), Chesapeake Bay, Maryland, but its ecological role is not completely understood. C. virginica filters large volumes of water and efficiently filters particles larger than $3 \mu \mathrm{m}$ from the water column (Haven \& Morales-Alamo 1970). At high particle loads, oysters do not stop filtering but produce more pseudofeces (Haven \& Morales-Alamo 1966). Large amounts of biodeposits reflect a transport of particulate organic matter from the water column to the sediments (Jordan 1987), unless currents resuspend the material and transport it away (Lund 1957, Widdows et al. 1998).

It has also been suggested that nutrient regeneration from bivalve biodeposits may counterbalance the removal of phytoplankton biomass by stimulating new phytoplankton blooms (Doering et al. 1986, Asmus \& Asmus 1991). High rates of ammonium flux can occur in sediments underlying natural bivalve populations (Dame et al. 1989, 1991, Dame \& Libes 1993, Asmus \& Asmus 1991), but other factors such as microphytobenthos abundance also affect nutrient transformations and regeneration (Sundbäck \& Graneli 1988, Sundbäck et al. 1991, 2000). Incubation experiments have shown that particulate organic matter, oxygen conditions, and microphytobenthos abundance affect nitrogen transformations and regeneration from the sediments (Caffrey et al. 1993, Enoksson 1993, Newell et al. 2002).

Water flow is an important variable in nature and affects processes such as (1) feeding behavior and food availability for macrofauna (Diaz \& Schaffner 1990, Taghon \& Greene 1992), (2) feeding interactions (Fréchette et al. 1989), (3) particle aggregations in the water column (Hill 1992), and (4) the erosion and transport of particulate matter or biodeposits (Widdows et al. 1998). Water flow can alter the direction and magnitude of process pathways and affect benthic-pelagic coupling. bottom shear velocity (shear stress) affects diffusional processes at the sediment-water interface (Dade 1993, Sanford \& Crawford 2000), sediment erosion (Maa et al. 1993), microphytobenthos erosion (Madsen et al. 1993, Yallop et al. 1994, Sutherland et al. 1998), and possibly nutrient transformations and regeneration (Boynton 1985, Santschi et al. 1990). Benthic suspensions feeders and flow interact in many ways (Wildish \& Kristmanson 1997).
Whole-ecosystem experiments are required to capture direct and indirect benthic-pelagic interactions, providing the most realistic ecosystem results. Previous studies of bivalve ecological functions have ranged from highly controllable laboratory studies with short response times and no feedback loops (e.g. Wright et al. 1982, Swanberg 1991, O'Riordan et al. 1993, Ward et al. 1998), to experiments in field flumes (Asmus et al. 1992, 1998), to very realistic but largely uncontrollable whole-ecosystem field studies (e.g. Dame \& Libes 1993) that include all the direct and indirect interactions and feedbacks. Benthic boundary-layer processes can be realistically represented in flumes but, with few exceptions (Asmus et al. 1992), water-column processes generally are not. In isolated tanks, watercolumn processes can be mimicked well (Peters \& Redondo 1997, Sanford 1997), but processes at the sediment-water interface are distorted (Sullivan et al. 1991, Crawford \& Sanford 2001, Porter et al. 2004, this volume). In linked flume/tank mesocosms (Porter et al. 2004), both water-column processes and benthic boundary-layer flow can be represented realistically, allowing for ecosystem experiments with enhanced bottom shear velocity, realistic water-column turbulence, and a realistic ratio of water-column turbulence levels to bottom shear velocity.

To study the effect of oysters and benthic boundarylayer flow on benthic-pelagic coupling processes in a controllable whole-ecosystem context, we used $1000 \mathrm{l}$ experimental ecosystems with the same realistic water-column turbulence levels (turbulence intensity of $1 \mathrm{~cm} \mathrm{~s}^{-1}$ ) but different levels of bottom shear velocity (Porter et al. 2004). Experiments were run with and without juvenile oysters Crassostrea virginica. Our linked mesocosm had a moderately enhanced bottom shear velocity of $0.6 \mathrm{~cm} \mathrm{~s}^{-1}$, whereas bottom shear velocity in our standard cylindrical mesocosms was unrealistically low at $0.1 \mathrm{~cm} \mathrm{~s}^{-1}$. Mesocosms with oysters were stocked at levels similar to oyster abundances in historic times in Chesapeake Bay (i.e. Newell 1988), with appropriate scaling to water volume (Porter 1999) using batch-feeding experiments. The specific questions we sought to address were: (1) How do oysters and bottom shear velocity affect phytoplankton abundance in whole-ecosystem experiments? (2) How do oysters and bottom shear velocity affect nutrient transformations and nutrient regeneration from the sediments? (3) How do oysters and bottom shear velocity affect overall water quality in whole-ecosystem experiments? Our experiments were designed to determine if the combined effect of oysters and increased bottom shear velocity directly, indirectly, or non-linearly affected ecosystem processes and shifted ecosystem function to the sediments. 


\section{MATERIALS AND METHODS}

Physical and biological scaling. Treatments consisted of an isolated tank with oysters, a linked mesocosm with oysters, and an isolated tank without oysters (Fig. 1). The linked mesocosm consisted of an annular flume with a diameter of $1.80 \mathrm{~m}$ and a water-column height of $15 \mathrm{~cm}$ that was connected to a modified water-column tank via an air-lift pump. In the linked mesocosm, bottom shear stress and water-column turbulence intensity could be set independently in each device. The linked mesocosm design is described in more detail in Porter et al. (2004).

All mesocosms had a 1 m-deep water column, a $1000 \mathrm{l}$ volume, and a $1 \mathrm{~m}^{2}$ sediment surface area of ca. $10 \mathrm{~cm}$ deep muddy sediment. While water-column mixing was the same in all systems, with turbulence intensities of about $1 \mathrm{~cm} \mathrm{~s}^{-1}$, bottom shear velocity was moderate $\left(0.6 \mathrm{~cm} \mathrm{~s}^{-1}\right)$ in the linked mesocosm and unrealistically low (about $0.1 \mathrm{~cm} \mathrm{~s}^{-1}$ ) in the isolated tanks (Porter 1999, Porter et al. 2004). To determine turbulence intensities, we used a combination of gypsum dissolution techniques (as appropriate in certain flow conditions, Porter et al. 2000) and direct flow/ turbulence measurements with an acoustic Doppler velocimeter (ADV) at different mixing speeds at a number of representative locations in our experimental ecosystems (Porter et al. 2004). Turbulence intensity was defined as in Tennekes \& Lumley (1972):

$$
q=\sqrt{\frac{1}{3}\left(<u^{2}>+<v^{2}>+<W^{2}>\right)}
$$

where $\left\langle u^{2}\right\rangle,\left\langle V^{2}\right\rangle$, and $\left\langle W^{2}\right\rangle$ are the variances of their respective velocity components. Turbulence intensities of $1 \mathrm{~cm} \mathrm{~s}^{-1}$ are at the lower end of intensities in natural systems and allowed energy dissipation rates in the systems to remain at reasonable levels. We used a combination of qualitative, quantitative, and semi-empirical engineering techniques to determine the benthic shear velocities (Porter 1999, Porter et. al 2004). Shear (or 'friction') velocity $\left(u_{*}\right)$ expresses the boundary-layer shear stress on a velocity scale:

$$
u_{*}=\sqrt{\frac{\tau_{\mathrm{b}}}{\rho}}
$$

where $\tau_{\mathrm{b}}$ is bottom shear stress and $\rho$ is the density of water. To quantify shear velocity directly at the bottom of each system, we used hot-film anemometry (Fingerson \& Freymuth 1983, Gust 1988).

Each experiment consisted of 3 mesocosms. An additional set of small mesocosms of different shape was run in parallel (Porter 1999, Porter et al. 2004). We added the same biomass of juvenile, ca. $2.5 \mathrm{~cm}$ long oysters Crassostrea virginica (Gmelin) to the linked mesocosm and 1 isolated tank, and no oysters to a second isolated tank. We performed triplicate sequential $4 \mathrm{wk}$ long indoor ecosystem experiments in summer 1995 (Expt 1), fall 1995 (Expt 2), and in spring 1996 (Expt 3). In a pilot experiment without oysters (Porter 1999), we determined that the isolated tanks and the linked mesocosm had similar levels of phytoplankton biomass.

We scaled the biomass of oysters to filter the entire water column about once every $1.5 \mathrm{~d}$ to represent historic oyster abundances in Chesapeake Bay as estimated by Newell (1988). Based on measured filtration rates of juvenile, ca. $2.5 \mathrm{~cm}$ long, oysters, we distributed a total of $228 \mathrm{~g}$ live weight, i.e. about 113 individually numbered and preweighed juvenile oysters, randomly across the bottom on Day 2 of each experiment. Oyster weight gain over the experiment was determined at the end of each experiment from many oysters with still identifiable numbers.

Experimental setup and water-column measurements. Muddy surface sediment was collected with buckets from the shallow mesohaline Choptank River, a Chesapeake Bay tributary, and treated in a holding tank that was covered with black plastic for $4 \mathrm{~d}$ to render it anaerobic and free of live macrobenthos. It was distributed into trays that fit the mesocosms, scraped flat, and kept in flow-through filtered estuarine water in the dark for $14 \mathrm{~d}$. In a separate study we found that this procedure killed macrofauna and produced realistic pore-water gradients within a $2 \mathrm{wk}$ period (Porter 1999). After defaunation and chemical stabilization, organisms of choice can be added to test
Fig. 1. Experimental ecosystems with and without oysters. All systems had $1000 \mathrm{l}$ water volume, $1 \mathrm{~m}^{2}$ sediment surface area, and were $1 \mathrm{~m}$ deep. $\mathrm{m}$ : isolated tank mesocosm without oysters; m+oys: isolated tank mesocosm with oysters; L+oys: linked mesocosm with oysters
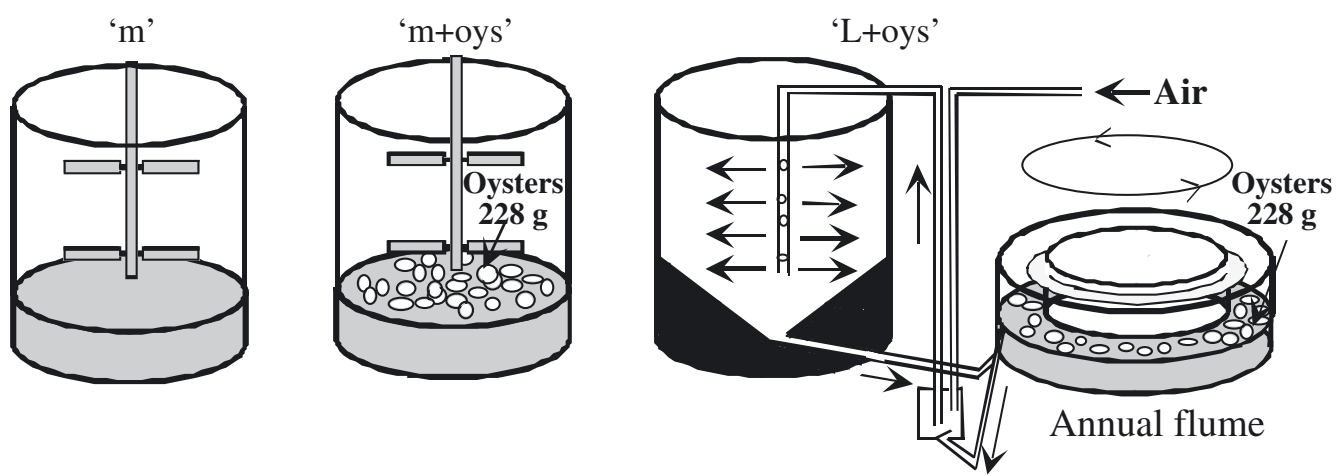
hypotheses on the effect of bottom shear stress and organisms on ecosystem processes.

At the start of each experiment, the sediment trays were placed into all mesocosms, providing a $10 \mathrm{~cm}$ sediment layer. The systems were then filled with unfiltered estuarine water from the Choptank River and appropriate biomasses of oysters.

The experiments were housed indoors. A simulated day-night cycle of 12:12 h light:dark was provided from broad-spectrum fluorescent bulbs. Daylight levels at the water surface were set to about $160 \mu \mathrm{E} \mathrm{m}^{-2}$ $\mathrm{s}^{-1}$, sufficient to produce phytoplankton blooms in this shape of mesocosm. Water temperatures in the experiments were $22 \pm 1^{\circ} \mathrm{C}$. Illumination of the sediment surface of the linked systems was adjusted to that of the surface sediment in the $1 \mathrm{~m}$ deep tanks by using shading mesh. To mimic tidal exchange we replaced $10 \%$ of the water in each system daily with $0.5 \mu \mathrm{m}$ filtered estuarine Choptank river water. Within the first $3 \mathrm{~d}$ of each experiment we added a nutrient spike of ammonium and soluble reactive phosphorus (SRP) at the Redfield ratio, increasing initial ammonium and SRP levels in the tanks by about 25 and $1.6 \mu \mathrm{M}$, respectively, to stimulate a phytoplankton bloom. We cleaned mesocosm walls of wall periphyton biweekly or more often to minimize wall growth (Chen et al. 1997, 2000).

Biological and geochemical variables included watercolumn chlorophyll $a$, water-column nutrient concentrations (ammonium, nitrate + nitrite, dissolved inorganic nitrogen [DIN], SRP, silicate), oyster growth rate, light at the sediment surface, and sediment chlorophyll a. Water-column nutrients were analyzed following Zimmerman et al. (1977) and Parsons et al. (1984). Pre- and postexperiment flux rates of nutrients and gases were determined from sediment flux incubations with sediment from the mesocosms as described below.

Chlorophyll a concentrations were measured fluorimetrically after filtration on Whatman GFF glass-fiber filters (Lorenzen 1967). Water-column nutrient concentrations were measured every 2 to $3 \mathrm{~d}$, and the data from all experiments from $2 \mathrm{~d}$ after the spike until the end of the experiment were included in statistical analyses. To determine oyster growth rate over each experiment, individual oysters were marked and their live weight measured before and after each experiment. We measured light profiles (downwelling attenuation) regularly with a Li-Cor light meter, calculated the attenuation coefficient, and calculated light levels at the bottom.

Sediment chlorophyll a measurements. Chlorophyll a concentration in the surface sediment was measured at the end of Expts 2 and 3, with weekly sediment chlorophyll a measurements in Expt 3 . The 0 to $0.5 \mathrm{~cm}$ surface sediment layer was sampled using $2.5 \mathrm{~cm}$ diameter coring devices with 3 replicates for all time points (9 replicates at end) and frozen at $-80^{\circ} \mathrm{C}$ until analysis. Sediment chlorophyll a was analyzed using high-performance liquid chromatography (Van Heukelem et al. 1992, 1994) to exclude interferences of degradation products such as pheophytin, chlorophyllides, and pheophorbides abundant at areas with bivalves (e.g. Karakassis et al. 1998).

We extracted sediment chlorophyll a by adding $20 \mathrm{ml}$ of $100 \%$ acetone to the sample tubes, sonicated each tube for 15 cycles at $0^{\circ} \mathrm{C}$, and let the sample extract further in a freezer overnight. After decanting, we then added an additional $20 \mathrm{ml}$ of $90 \%$ acetone, sonicated the sample again, and let the sample extract for another $3 \mathrm{~h}$. The supernatant was decanted after centrifugation and subsequently analyzed by highperformance liquid chromatography (Van Heukelem et al. 1992, 1994). In prior tests we had found that this technique efficiently extracted about $97 \%$ of the sediment chlorophyll a from sediments containing a range of sediment chlorophyll a concentrations. Extracts from replicate samples were pooled and analyzed for chlorophyll $a$, pheophytin $a$, pheophorbide, and chlorophyllide $a$. Because samples from Expt 2 were analyzed more than $3 \mathrm{mo}$ after the respective experiments, some degradation of chlorophyll a could have taken place, and for Expt 2 we report the sediment chlorophyll a values plus all degradation products.

Sediment flux experiments. At the end of the mesocosm experiments, we removed 3 sediment cores per mesocosm using $13.3 \mathrm{~cm}$ diameter, clear, acrylic benthic chambers. We added filtered water to the benthic chambers, sealed the chambers air-tight, added stirring, and incubated the cores first in the dark and then in the light to obtain sediment oxygen, ammonium, nitrate + nitrite, nitrogen gas $\left(\mathrm{N}_{2}-\mathrm{N}\right)$ dark and light flux rates, and daily flux rates for each chamber plus control chambers that did not have any sediment. Nutrient and gas flux rates from the sediments were corrected for water-column processes using data from chambers run without sediment. Nutrient samples were frozen at $-20^{\circ} \mathrm{C}$ and later analyzed following Zimmerman et al. (1977) and Parsons et al. (1984). Nitrogen gas flux rates were determined using a modified membrane inlet mass spectrometer (Kana et al. 1994). We did not determine sediment nutrient and gas flux rates in the light for Expt 1 but did so for Expts 2 and 3. Sediments at the start of an experiment were taken from the flowthrough water bath and incubated in the dark only.

Statistical analyses of experimental ecosystem variables. In this series of experiments, the position of each of the 3 treatments was rotated to follow the pattern of a latin square (Steel \& Torrie 1980, and present Fig. 2). Latin-square analyses of variance included the data of a variable from all experiments in the analysis. Responses on sediment-flux cores with dark and light 


\begin{tabular}{|c|c|}
\hline & Position \\
\hline Expt 1 & $\mathrm{a} \quad \mathrm{b} \quad \mathrm{c}$ \\
\hline Expt 2 & b c a \\
\hline Expt 3 & c a b \\
\hline
\end{tabular}

Fig. 2. Experimental design of latin square analysis of variance (adapted after Steel \& Torrie 1980). For each experiment (Expts 1, 2, 3 = summer and fall 1995 and spring 1996), position of each tank (i.e. a, b, c) was changed to a different location to eliminate location effects

incubations added a split plot or repeated-measures dimension to the design (sediment oxygen, ammonium, nitrate+nitrite, dissolved inorganic nitrogen, nitrogen gas, silicate fluxes). Analysis of variance was applied to individual experiments when data for 1 of the 3 experiments were lost (sediment chlorophyll data from Expt 1) or not measured (light sediment flux rates in Expt 1), and repeated significant effects of the same direction over multiple experiments were taken as indicative of an overall effect. Statistical analyses were performed using SAS (SAS Institute). Assumptions of the normality and the homogeneity of the error term were checked using Shapiro-Wilks and Levene's tests, respectively, and the data transformed when necessary.

\section{RESULTS}

\section{Water-column processes}

Water-column chlorophyll a levels, an index of phytoplankton biomass, were significantly lower in systems with oysters than in the isolated tank without oysters (Fig. 3). There were no significant differences in water-column chlorophyll a concentrations between the linked mesocosm with oysters and the isolated tank with oysters, although the rate of change of phytoplankton biomass per day, on the basis of total $228 \mathrm{~g}$ live oyster biomass per tank, was larger in the isolated tank with oysters $\left(-17.4 \times 10^{-4} \pm 22.1 \times 10^{-4}\right)$ than in the
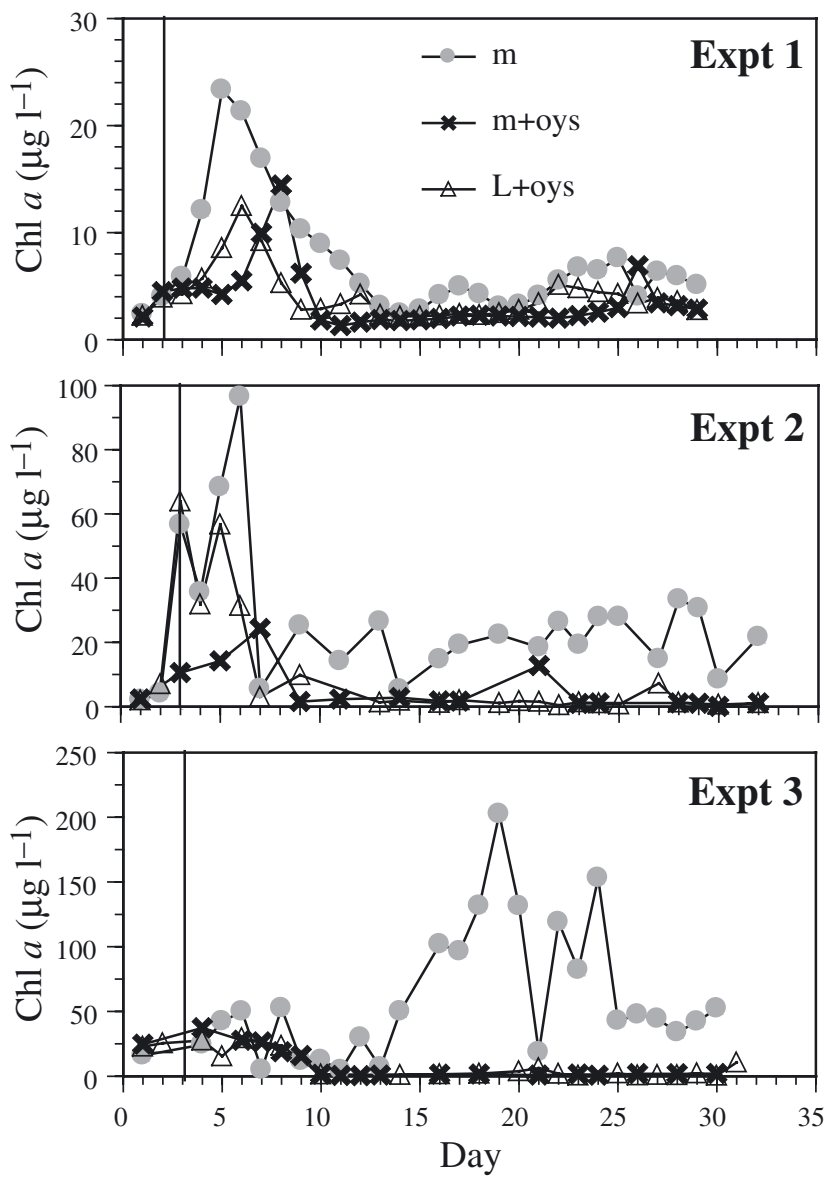

Fig. 3. Water-column chlorophyll a concentrations over time in 3 sequential experiments. Vertical line: time when oysters and nutrients were added. See Fig. 1 for treatments

linked mesocosm with oysters $\left(+1.9 \times 10^{-4} \pm 4.3 \times 10^{-4}\right)$. In addition, in all experiments, systems with oysters did not have a second phytoplankton bloom, whereas blooms developed in the isolated tank mesocosm either after the start (Expts 1 and 2) or towards the middle of the experiment (Expt 3).

Oysters grew slightly better in the linked mesocosms (Fig. 4), the results were not statistically significant. However, oyster feeding significantly increased light penetration through the water column and to the

Table 1. Results of latin square ANOVA of the 3 experiments for water-column chlorophyll a concentrations, light levels at bottom, dissolved oxygen concentrations, and water-column nutrient concentrations. SRP: soluble reactive phosphorus. Probabilities at $0.1>\mathrm{p}>0.05$ are non-significant and only suggestive of a trend; boldface indicates statistical significance and trends. See Fig. 1 for treatments

\begin{tabular}{|lcccccccccc}
\hline Comparison & $\begin{array}{c}\text { Water-column } \\
\text { chl } a\end{array}$ & $\begin{array}{c}\text { Light at } \\
\text { bottom }\end{array}$ & $\begin{array}{c}\text { Dissolved } \\
\text { oxygen }\end{array}$ & Ammonium & Nitrate + nitrite & DIN & SRP & Silicate \\
\hline $\mathrm{m}$ & vs & m+oys & $\mathbf{p}=\mathbf{0 . 0 1 4 7}$ & $\mathbf{p = 0 . 0 3 7 6}$ & $\mathrm{p}=0.2318$ & $\mathbf{p = 0 . 0 7 3 5}$ & $\mathrm{p}=0.4773$ & $\mathrm{p}=0.4272$ & $\mathrm{p}=0.1926$ & $\mathrm{p}=0.5567$ \\
$\mathrm{~m}$ & vS L+oys & $\mathbf{p}=\mathbf{0 . 0 2 2 3}$ & $\mathbf{p = 0 . 0 2 3 6}$ & $\mathrm{p}=0.2677$ & $\mathbf{p}=\mathbf{0 . 0 8 1 3}$ & $\mathrm{p}=0.7247$ & $\mathrm{p}=0.6758$ & $\mathrm{p}=0.5915$ & $\mathrm{p}=0.5564$ \\
$\mathrm{~m}+$ oys vs & L+oys & $\mathrm{p}=0.2580$ & $\mathrm{p}=0.3019$ & $\mathrm{p}=0.8767$ & $\mathrm{p}=0.6996$ & $\mathrm{p}=0.7133$ & $\mathrm{p}=0.6978$ & $\mathrm{p}=0.4128$ & $\mathrm{p}=0.2547$ \\
\hline
\end{tabular}



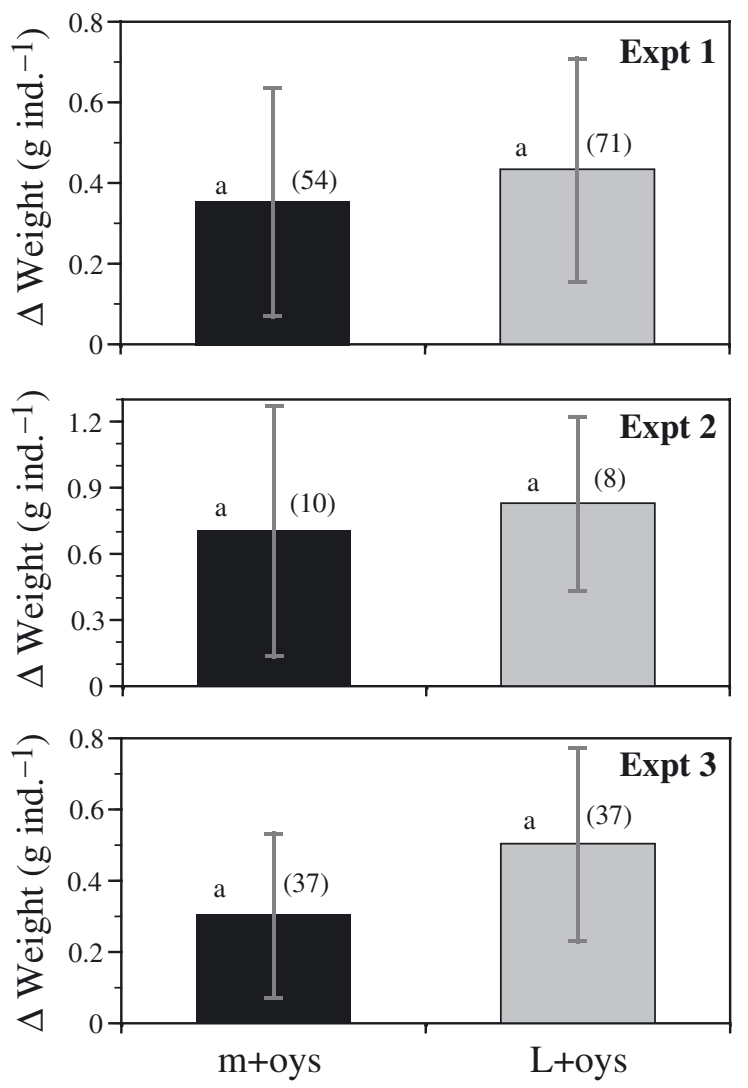

Fig. 4. Oyster live weight changes (including shell; mean \pm $\mathrm{SD})$ during each experiment. Numbers in parantheses: numbers of oysters recovered with identifiable numbers after experiment and included in analysis. Different letters indicate significant differences in live oyster weight gain (ANOVA and Student-Newman-Keuls analysis, $\mathrm{p}<0.05$ ). See Fig. 1 for treatments

sediments (Fig. 5, Table 1). There were no significant differences between light levels in the isolated tank with oysters and the linked mesocosm with oysters (Fig. 5, Table 1).

Water-column nutrient concentrations such as nitrate + nitrite, dissolved inorganic nitrogen, and silicate, averaged from Day 2 after the spike to the end of the experiments, were not significantly different among the isolated tank, the isolated tank with oysters, and the linked mesocosm (Fig. 6, Table 1). Ammonium showed a trend of being enhanced in the isolated tank with oysters and the linked mesocosm with oysters compared to the isolated tank without oysters (Table 1). Variability in overall nutrient concentrations was high between Expts 1,2, and 3 because the experiments were performed during different seasons (Fig. 6). Water-column dissolved oxygen levels were not significantly different between the isolated tank, the isolated tank with oysters, and the linked mesocosm with oysters (Table 1) and ranged between 6.5 and $13 \mathrm{mg} \mathrm{l}^{-1}$.
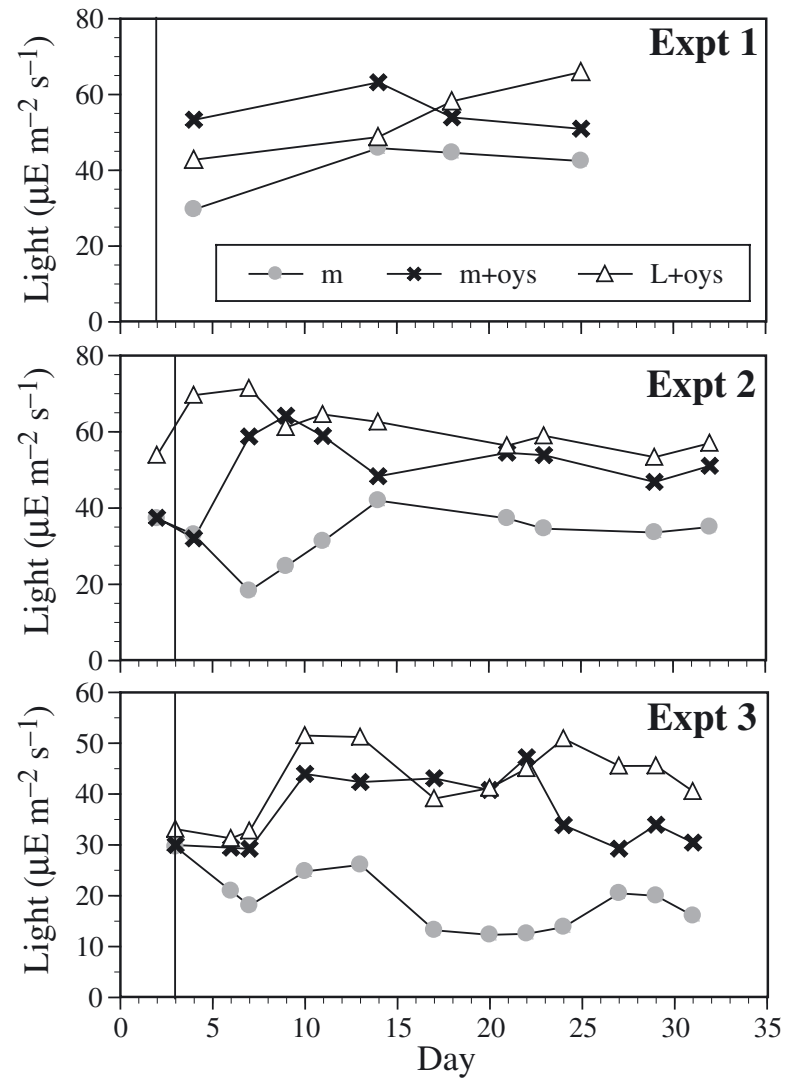

Fig. 5. Light levels at sediments over time in each of 3 experiments. Statistical results in Table 1. Vertical line: time when oysters and nutrients were added. See Fig. 1 for treatments

\section{Processes at sediment-water interface}

Sediment chlorophyll a

(index of microphytobenthos biomass)

Sediment chlorophyll a concentrations at the end of Expts 2 and 3 (Fig. 7) ranged from 80 to 120 and 80 to $450 \mathrm{mg} \mathrm{m}^{-2}$, respectively, and were significantly lower in the linked mesocosm with oysters than in the isolated tank with oysters. Sediment chlorophyll a concentrations were significantly higher in the isolated tank with oysters compared to the isolated tank without oysters. Overall sediment chlorophyll a concentrations were significantly higher in Expt 3 than Expt 2.

During Expt 3, we measured sediment chlorophyll a concentrations weekly (Fig. 8). Sediment chlorophyll $a$ concentrations increased similarly in all tanks to about $100 \mathrm{mg} \mathrm{m}^{-2}$ over the first $2 \mathrm{wk}$. However, after $14 \mathrm{~d}$, sediment chlorophyll a concentrations increased in the isolated and the linked mesocosm with oysters but not in the isolated tank without oysters. While sediment chlorophyll a concentrations increased similarly to about $280 \mathrm{mg} \mathrm{m}^{-2}$ in the isolated tank with oysters 

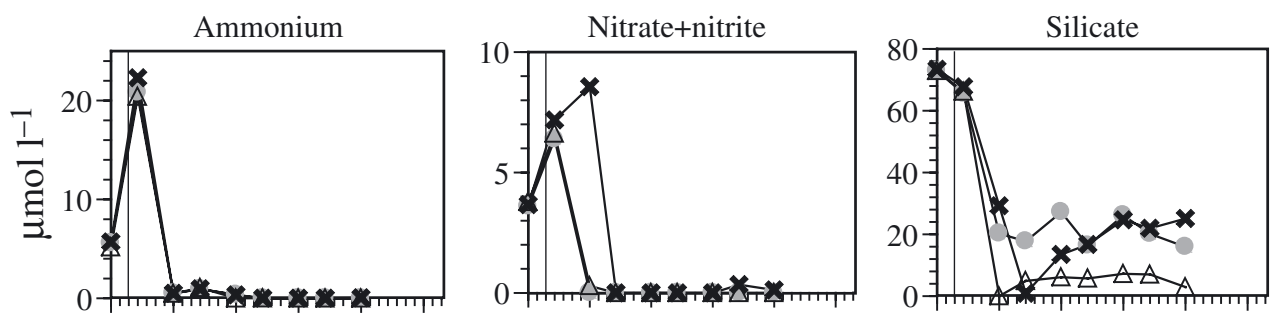

Soluble reactive phosphorus
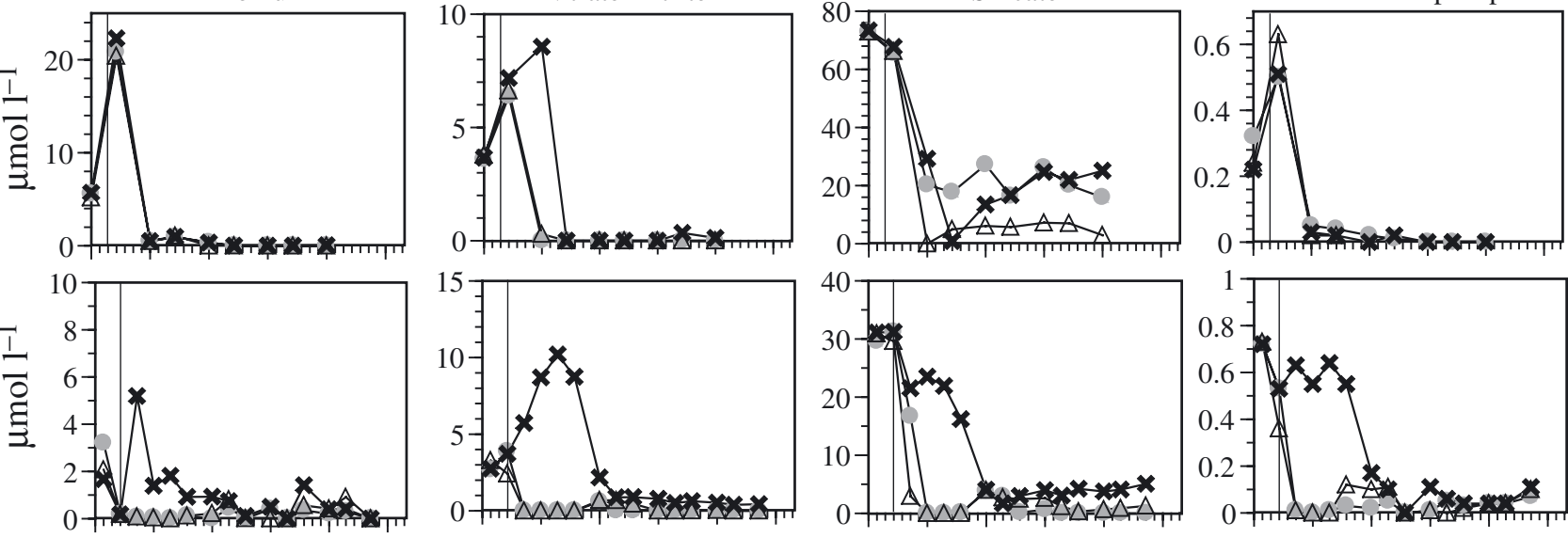

Expt 1
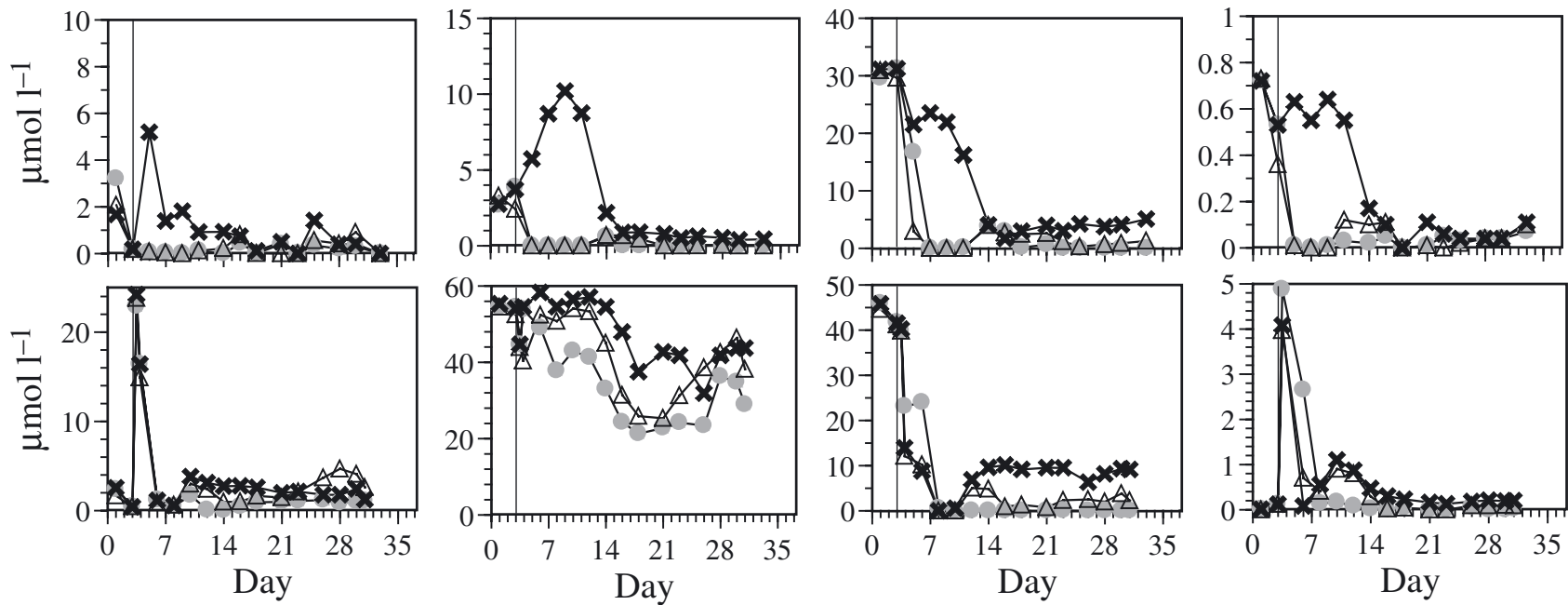

Expt 2

Fig. 6. Water-column nutrient concentrations over time in each of 3 experiments. Lines indicate days of nutrient spikes to the systems. Statistical results in Table 1. Vertical line: time when oysters and nutrients added. See Fig. 1 for treatments

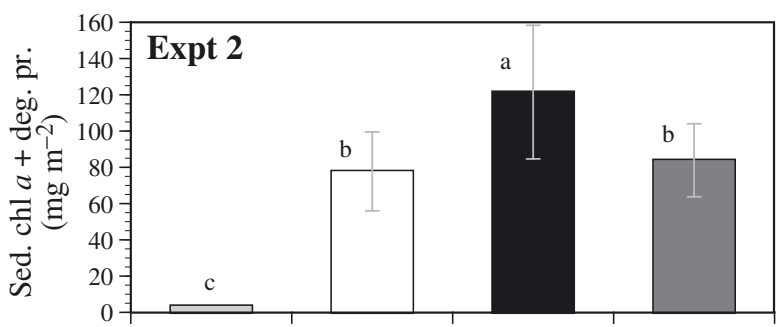

and the linked mesocosm with oysters from Days 14 to 21, sediment chlorophyll a concentrations increased from 300 to $330 \mathrm{mg} \mathrm{m}^{-2}$ from Days 21 to 28 in the isolated tank with oysters but decreased sharply from 250 to $120 \mathrm{mg} \mathrm{m}^{-2}$ in the linked mesocosm with oysters (Fig. 8). The decrease of sediment chlorophyll a coincided with direct observations of patches of micro-

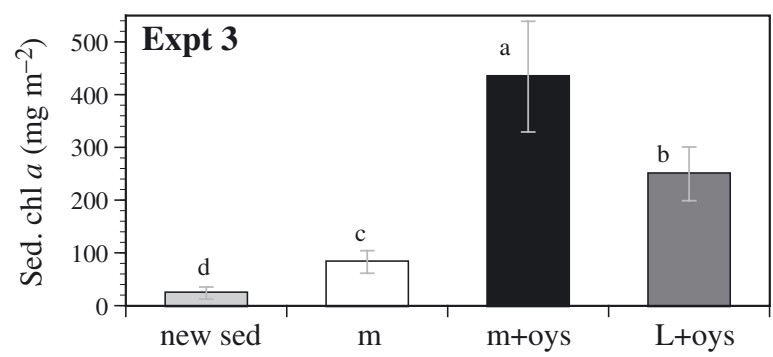

Fig. 7. Sediment chlorophyll a (Sed. chl a) concentrations (an indicator of microphytobenthos biomass) at end of Expts 2 and 3 (data lost for Expt 1). Results from Expt 2 include degradation products (degr. pr.). Bars represent mean $\pm \mathrm{SD}$ sediment chlorophyll a abundance; sample size: $\mathrm{n}=9$ except for new sediment $(n=3)$. Different letters indicate statistically significant differences between treatments. See Fig. 1 for treatments; new sed $=$ sediment at start of the experiment

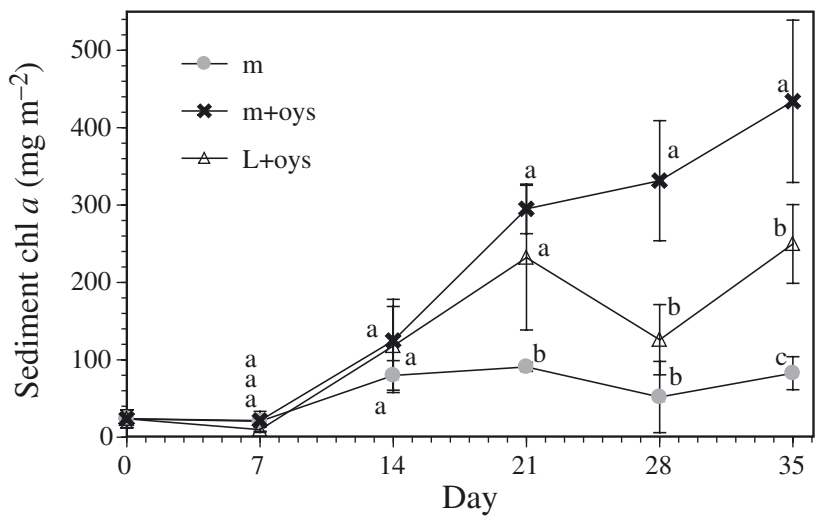

Fig. 8. Mean $( \pm \mathrm{SD})$ weekly sediment chlorophyll a concentrations (top $0.5 \mathrm{~cm}$ ) during Expt 3 in our treatments. Sample size: $\mathrm{n}=3$ on Days $0,7,14,21,28 ; \mathrm{n}=9$ on Day 35. Different letters represent statistical significances $(p<0.05)$ on individual days. See Fig. 1 for treatments 
phytobenthos being eroded after a period with oxygen bubbles in the mat. Although sediment chlorophyll $a$ abundance increased again after Day 28 in the linked mesocosm with oysters, sediment chlorophyll a concentrations remained significantly lower than in the isolated tank with oysters and significantly higher than in the isolated tank without oysters until the end of the experiment (Day 35) (Fig. 8). This shift in biomass suggests that the interaction of a moderately increased bottom shear and the age of the microphytobenthos eroded sediment chlorophyll $a$.
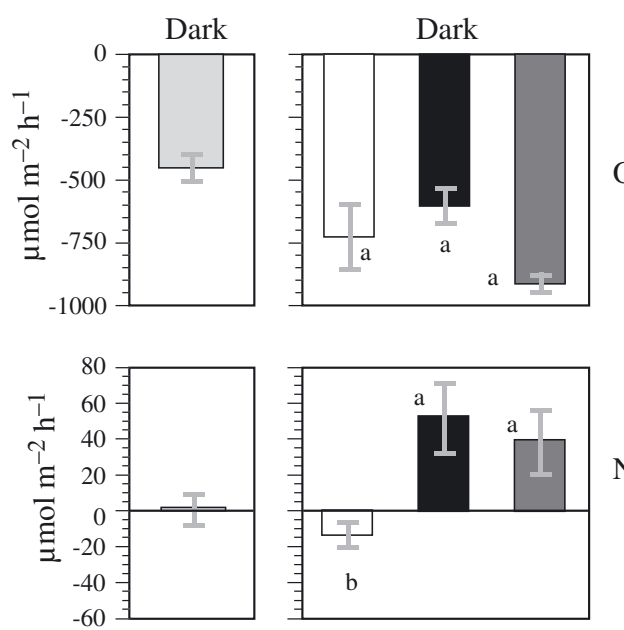

$\mathrm{NH}_{4}^{+}$
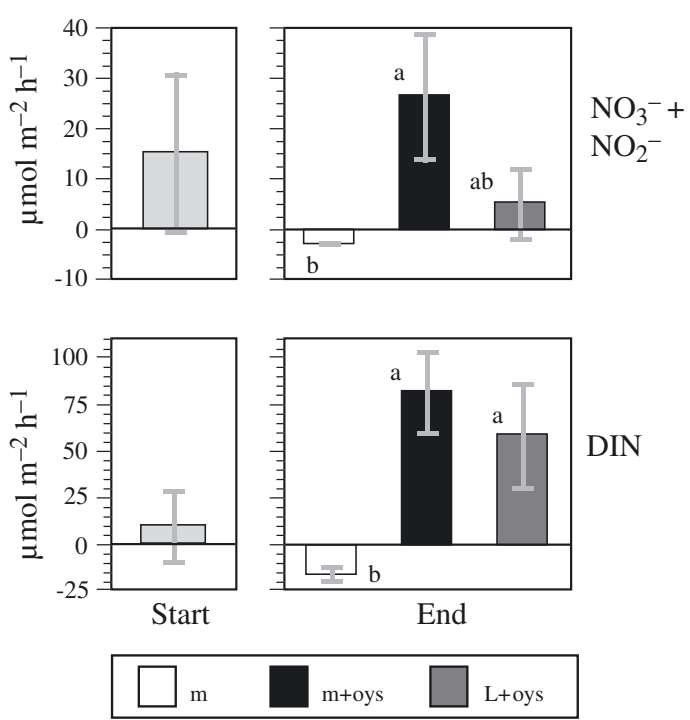

Fig. 9. Mean $( \pm \mathrm{SD})$ sediment nutrient (ammonium, nitrite + nitrate, DIN $\left[\mathrm{DIN}=\mathrm{NO}_{2}{ }^{-}+\mathrm{NO}_{3}{ }^{-}+\right.$ $\mathrm{NH}_{4}{ }^{+}$] and gas (dissolved oxygen) flux rates (positive $=$ sediment efflux, negative $=$ sediment uptake) before (Start) and after (End) Expt 1; $\mathrm{n}=3$. Dark incubations only. Different letters indicate significant differences; Student-Newman-Keuls, $\mathrm{p}<0.05$. All sediment incubations were carried out without oysters. See Fig. 1 for treatments

\section{Sediment nutrient and gas fluxes}

All sediment-flux experiments were performed without oysters to separate indirect biogeochemical responses from the direct effects of oyster feeding and metabolism. We observed oxygen uptake by the sediments in the dark, and oxygen release in the light (Figs. 9, 10 \& 11). Oxygen uptake in the dark ranged from -400 to about $-1000 \mu \mathrm{mol} \mathrm{m}{ }^{-2} \mathrm{~h}^{-1}$ at the end of all experiments. Oxygen uptake rates were not significantly different between the isolated tank, the isolated tank with oysters, and the linked mesocosm with oysters. Oxygen effluxes in the light ranged from +400 to $+6000 \mu \mathrm{mol} \mathrm{m}^{-2} \mathrm{~h}^{-1}$ in our systems. The significantly highest oxygen effluxes were observed in the isolated
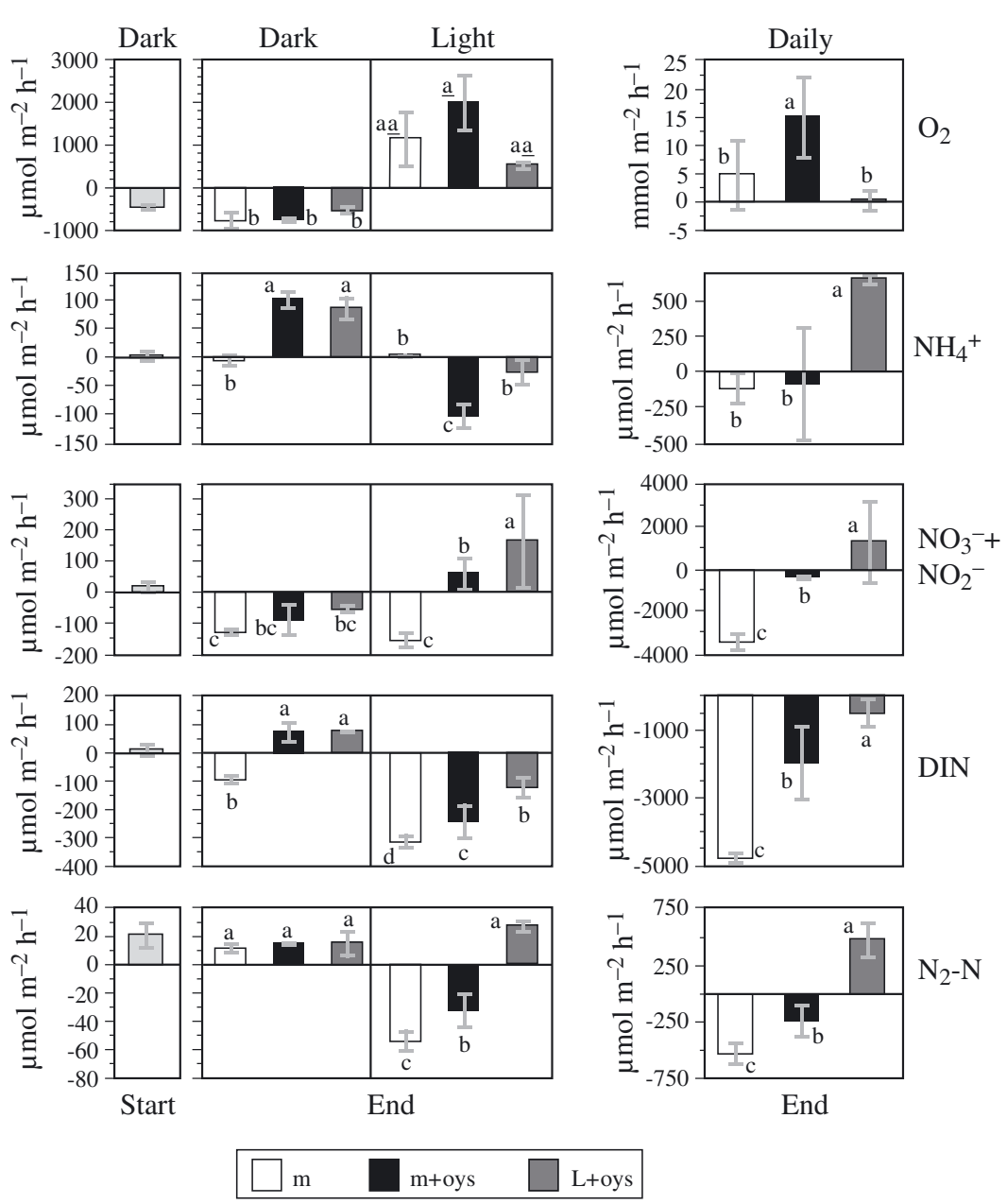

Fig. 10. Mean $( \pm \mathrm{SD})$ sediment nitrogen (ammonium, nitrite+nitrate, DIN [DIN $\left.=\mathrm{NO}_{2}^{-}+\mathrm{NO}_{3}^{-}+\mathrm{NH}_{4}{ }^{+}\right]$and gas (dissolved oxygen, nitrogen gas $=\mathrm{N}_{2}-\mathrm{N}$ ) dark, light, and daily flux rates (positive $=$ sediment efflux, negative $=$ sediment uptake) at start and end of Expt $2 ; \mathrm{n}=3$. Different letters indicate significant differences $(p<0.05)$, underscoring indicates trends $(p=0.05$ to 0.1$)$. All sediment incubations were carried out without oysters. See Fig. 1 for treatments 
tanks with oysters, with rates of +2000 and $+6000 \mu \mathrm{mol}$ $\mathrm{m}^{-2} \mathrm{~h}^{-1}$ in Expts 2 and 3, respectively (light phases, Figs. 10 \& 11). Net dark + light oxygen fluxes (reported here as daily rates) were also highest in the isolated tanks with oysters (Figs. 10 \& 11).

We observed sediment ammonium-flux rates ranging from +50 to $-110 \mu \mathrm{mol} \mathrm{m}^{-2} \mathrm{~h}^{-1}$ (Figs. 9, $10 \& 11$ ). In the dark we observed ammonium effluxes, and in the light ammonium uptake (Figs. 10 \& 11). At the end of Expt 2, we observed significantly higher ammonium effluxes $\left(100 \mu \mathrm{mol} \mathrm{m} \mathrm{m}^{-2} \mathrm{~h}^{-1}\right)$ in the linked and isolated mesocosm with oysters; in contrast, the isolated tank without oysters had a slight uptake $\left(-10 \mu \mathrm{mol} \mathrm{m} \mathrm{m}^{-2} \mathrm{~h}^{-1}\right)$. We found a daily dark + light sediment ammonium uptake in the mesocosm with oysters, with a rate of $-100 \mu \mathrm{mol} \mathrm{m} \mathrm{m}^{-2} \mathrm{~d}^{-1}$, but a sediment ammonium efflux of about $600 \mu \mathrm{mol} \mathrm{m} \mathrm{m}^{-2} \mathrm{~d}^{-1}$ in linked mesocosm with oysters in Expt 2 (Figs. 10 \& 11).
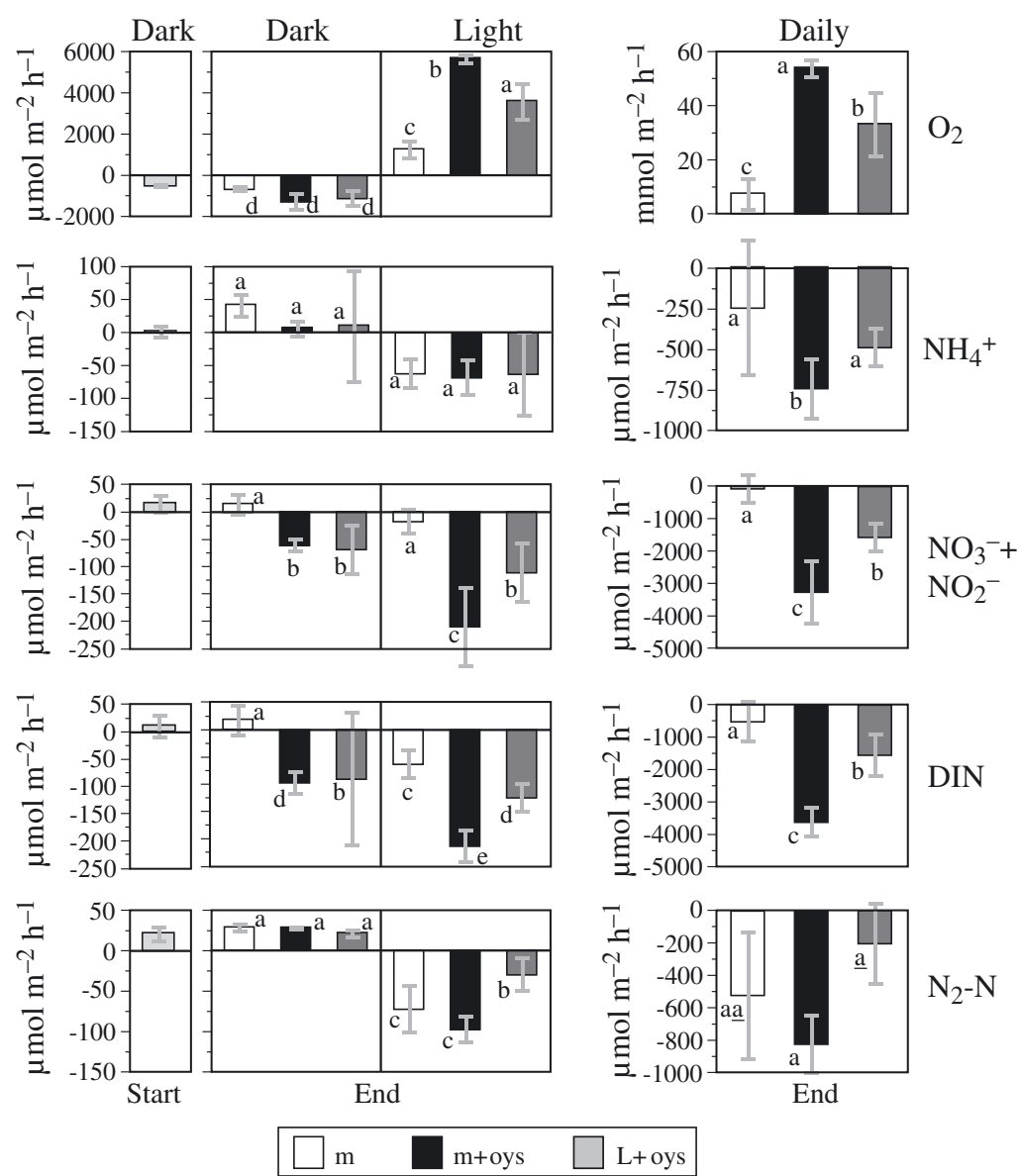

Fig. 11. Mean $( \pm \mathrm{SD})$ sediment nitrogen (ammonium, nitrite + nitrate, DIN $\left[\mathrm{DIN}=\mathrm{NO}_{2}{ }^{-}+\mathrm{NO}_{3}{ }^{-}+\mathrm{NH}_{4}{ }^{+}\right.$] and gas (dissolved oxygen, nitrogen gas $=\mathrm{N}_{2}{ }^{-}$ $\mathrm{N}$ ) dark, light, and daily flux rates (positive = sediment efflux, negative $=$ sediment uptake) at start and end of Expt $3 ; n=3$. Different letters indicate significant differences $(p<0.05)$, underscoring indicates trends $(p=0.05$ to 0.1). All sediment incubations were carried out without oysters. See Fig. 1 for treatments
Nitrate+nitrite flux rates ranged from +150 to $-200 \mu \mathrm{mol} \mathrm{m} \mathrm{m}^{-2} \mathrm{~h}^{-1}$ over the dark and light periods (Figs. 9, 10, 11) in all experiments with no consistent pattern of uptake or efflux. Overlying water nitrate+ nitrite concentrations for the flux cores were about 1 , 19 and $41 \mu \mathrm{mol} \mathrm{m}{ }^{-2} \mathrm{~h}^{-1}$ for Expts 1, 2 and 3, respectively, with ammonium concentrations ranging beween 1 and $3 \mu \mathrm{mol} \mathrm{m} \mathrm{m}^{-2} \mathrm{~h}^{-1}$. Daily nitrate+nitrite xes were significantly lower in the isolated tanks 11) but flux rates in the isolated tank without oysters were variable.

Dissolved inorganic nitrogen flux rates in all experiments ranged from +70 to $-275 \mu \mathrm{mol} \mathrm{m} \mathrm{m}^{-2} \mathrm{~h}^{-1}$ over the dark and light periods (Figs. 9, 10, 11). We observed slight efflux $\left(+70 \mu \mathrm{mol} \mathrm{m} \mathrm{m}^{-2} \mathrm{~h}^{-1}\right)$ or uptake $(-80 \mu \mathrm{mol}$ $\mathrm{m}^{-2} \mathrm{~h}^{-1}$ ) in the dark, whereas we found high uptakes $\left(-70\right.$ to $\left.-275 \mu \mathrm{mol} \mathrm{m}^{-2} \mathrm{~h}^{-1}\right)$ in the light. Dissolved inorganic nitrogen uptake rates were significantly higher in the isolated tank with oysters than in the linked mesocosm with oysters, with a greater difference observed in Expt 2 (-150 vs $+50 \mu \mathrm{mol} \mathrm{m} \mathrm{m}^{-2} \mathrm{~h}^{-1}$; Fig. 10) than in Expt 3 (300 vs $190 \mu \mathrm{mol} \mathrm{m} \mathrm{m}^{-2} \mathrm{~h}^{-1}$; Fig. 11). Daily DIN uptake rates were significantly higher in the isolated tank with oysters than in the linked mesocosm with oysters.

Nitrogen gas fluxes ranged from about +30 to $-100 \mu \mathrm{mol} \mathrm{m}{ }^{-2} \mathrm{~h}^{-1}$ (Figs. 10 \& 11) with overall nitrogen gas efflux in the dark and uptake in the light. Daily nitrogen gas uptake was significantly higher in the isolated tank with oysters than in the linked mesocosm with oysters (Figs. 10 \& 11).

\section{Overriding sediment relationships}

Sediment gross oxygen production (i.e. light $\mathrm{O}_{2}$ flux - dark $\mathrm{O}_{2}$ flux) was positively correlated $(\mathrm{p}<0.0001)$ to sediment chlorophyll a concentrations (Fig. 12a). In addition, daily dissolved inorganic nitrogen fluxes were negatively correlated $(\mathrm{p}=$ 0.0011) to sediment chlorophyll a except the cores from the isolated tank without oysters in Expt 2 (Fig. 12b). Furthermore, daily ammonium fluxes were negatively correlated ( $\mathrm{p}<0.0044)$ to sediment chlorophyll a (Fig. 12c); the outlier is due to a core run accidentally with an oyster. Nitrogen gas flux rates in the light decreased linearly with increasing sediment chloro- 

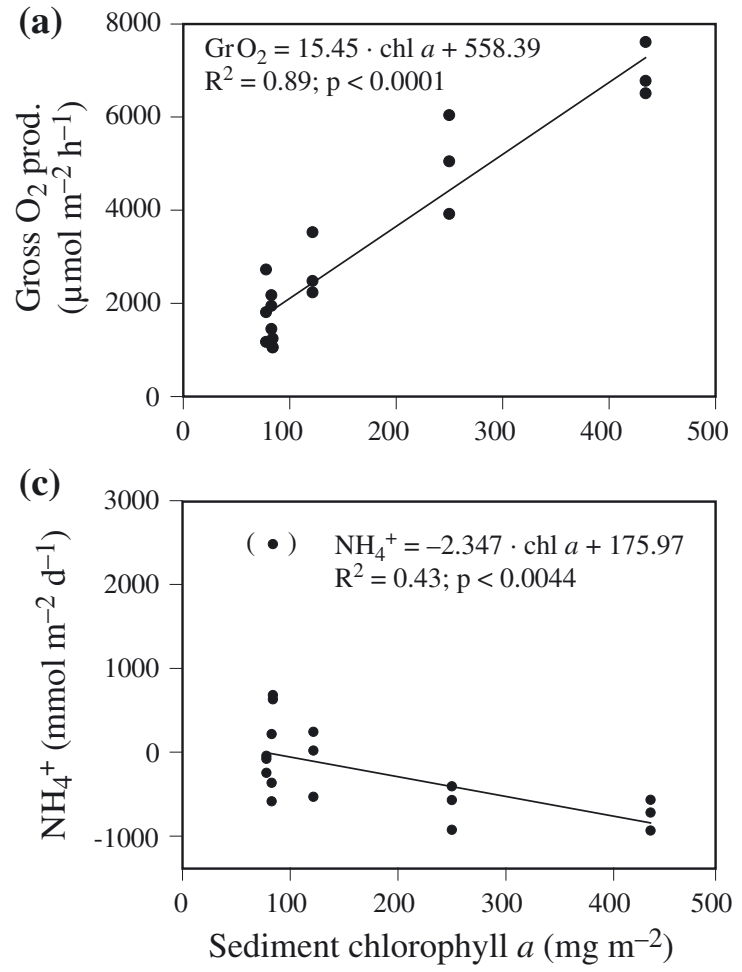
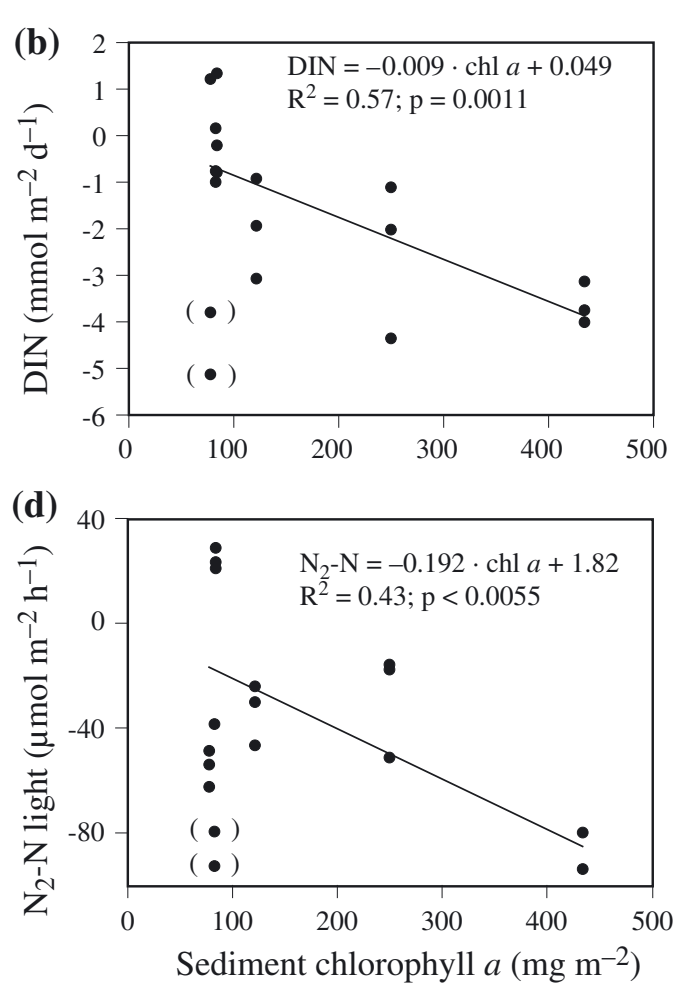

Fig. 12. Sediment-flux variables compared to sediment chlorophyll a concentration with all data from Expts 2 and 3 . (a) Gross oxygen production (i.e. dissolved oxygen flux in light minus dissolved oxygen flux in the dark) vs sediment chlorophyll a concentration; (b) daily dissolved inorganic nitrogen (DIN) concentration vs sediment chlorophyll a concentration; (c) daily ammonium flux rate vs sediment chlorophyll a concentration; (d) nitrogen gas $\left(\mathrm{N}_{2}-\mathrm{N}\right)$ flux rate in the light vs sediment chlorophyll $a$ concentration. Data points in parentheses were outliers and not included in statistical analyses

phyll a concentration (Fig. 12d); however, cores from the mesocosms without oysters in Expt 3 did not fit the pattern and had low nitrogen gas flux rates. We have observed high $\mathrm{N}_{2}-\mathrm{N}$ influxes in other systems with high microphytobenthic biomass and have had difficulty corroborating these apparent $\mathrm{N}$ fixation measurements with other measures of $\mathrm{N}$ fixation (E. Nagel \& J. C. Cornwell unpubl. data). There appears to be the potential for $\mathrm{N}_{2}$ flux artifacts associated with high $\mathrm{O}_{2}$ production.

Systems that had higher flux rates in the dark also had significantly higher flux rates in the light, i.e. they were significantly correlated $(p<0.0001$ ) (Fig. 13a). Nitrogen demand, calculated as the gross oxygen production divided by 6.625 (i.e. the Redfield ratio of C:N with 106:16, Kemp \& Cornwell 2003), increased significantly with increasing nitrogen supply, calculated as the sum of the light ammonium flux rate, the light nitrate + nitrite flux rate, and the light nitrogen gas flux rate (Fig. 13b). Nitrogen gas flux rates in the dark and nitrogen gas flux rates in the light, respectively, significantly increased linearly with increasing concentrations of nitrate+nitrite in the overlying water column (Fig. 14).

\section{DISCUSSION}

Direct and indirect interactions between oysters and moderate bottom shear velocity affected phytoplankton biomass, light availability, microphytobenthos biomass, and nutrient regeneration from the sediments to the water column, with implications for water quality in ecosystems. Oysters feeding significantly decreased phytoplankton biomass. The isolated tank without oysters repeatedly developed a phytoplankton bloom, while the mesocosms with oysters did not. A decrease in phytoplankton biomass, as mediated by oysters, repeatedly enhanced light penetration through the water column and to the sediments. Phytoplankton biomass and bottom light levels, however, were not significantly different between the isolated tank with oysters and the linked mesocosm with oysters. Light availability at the bottom enhanced microphytobenthos abundance but, conversely, a moderate bottom shear velocity of $0.6 \mathrm{~cm} \mathrm{~s}^{-1}$ eroded microphytobenthos as the mat aged, thus reducing microphytobenthos abundance. Bubble formation within the microphytobenthos community may have provided buoyancy and increased pore spaces and mat rough- 


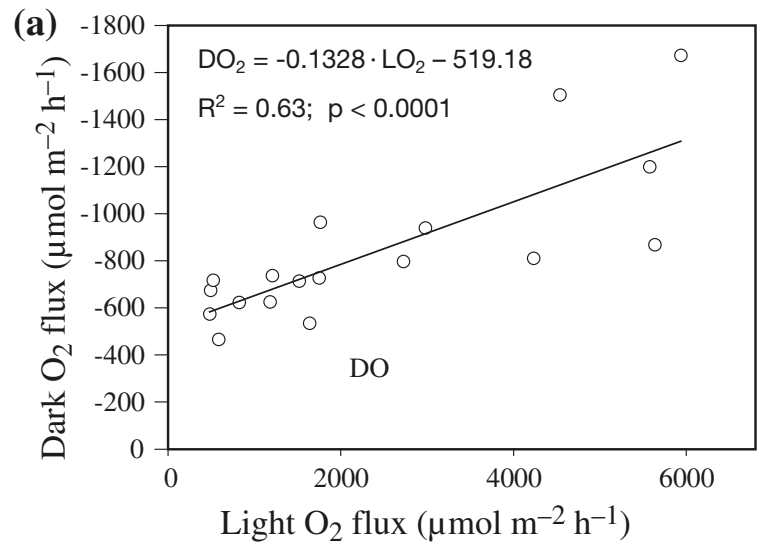

(b)

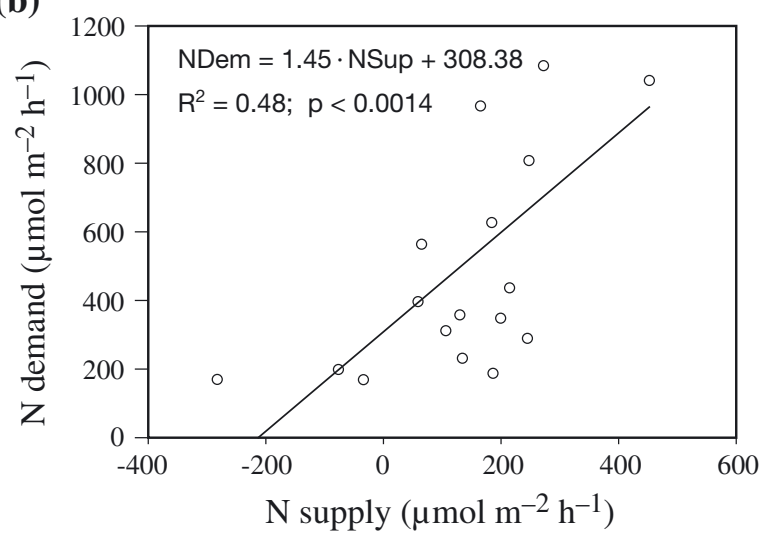

Fig. 13. (a) Dissolved oxygen flux rates in dark vs dissolved oxygen flux rates in light with all data from Expts 2 and 3. (b) Nitrogen demand vs nitrogen supply with all data from Expts 2 and 3. Nitrogen demand is gross oxygen production (i.e. dissolved oxygen flux in the light minus the dissolved oxygen flux in the dark) divided by 6.625. Nitrogen supply is sum of ammonium, nitrite, nitrate, and nitrogen gas $\left(\mathrm{N}_{2}-\mathrm{N}\right)$ flux rates in light

ness, decreasing the critical erosional threshold. The microphytobenthos biomass dominated nutrient feedbacks from the sediments to the water column.

Across all experiments, we found a strong positive relationship between gross oxygen production and the concentration of sediment chlorophyll $a$, indicating photosynthesis.

The large range of sediment oxygen fluxes in the light contrasted strongly with the small range of sediment oxygen fluxes in the dark, with an apparent predominance of production over respiration. Despite a positive correlation between production and respiration, the lower rates of respiration suggest that at an assumed steady state, respiration may not be the only organic matter loss term. Depleted water-column chlorophyll a levels after the blooms suggest that oysters were probably food-limited over large periods of the experiments, with a concomitant reduction in biodeposition.
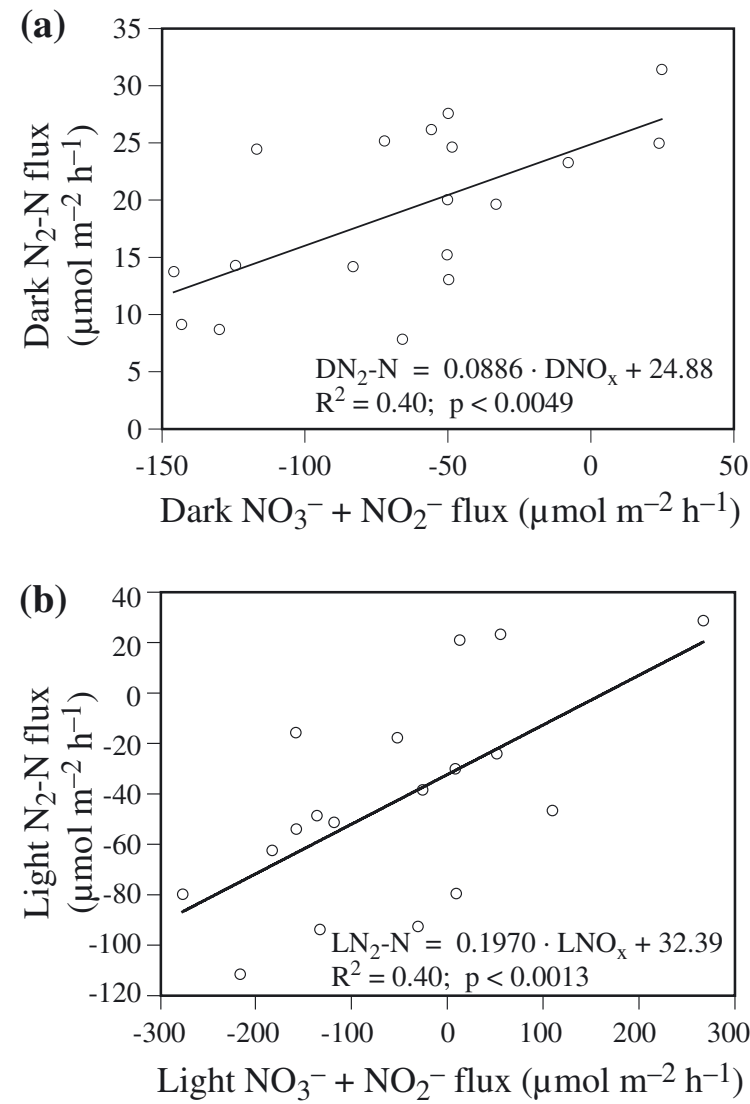

Fig. 14. (a) Nitrogen gas flux $\left(\mathrm{N}_{2}-\mathrm{N}\right)$ in (a) dark vs nitrate + nitrite flux in dark with all data from Expts 2 and 3, and (b) in light vs nitrate+nitrite flux in light with all data from Expts 2 and 3

We observed a significant increase in the daily sediment ammonium and dissolved inorganic nitrogen uptake with increasing sediment chlorophyll a abundance. Thus microphytobenthos significantly reduced the overall amount of regenerated $\mathrm{N}$ that was returned to the water column. The daily nitrogen release to the water column was lowest in the system with the highest concentrations of sediment chlorophyll $a$. Thus, the daily sediment nitrogen release was mediated by light availability at the bottom and by an enhanced bottom shear stress that eroded and thus decreased microphytobenthos biomass.

Nitrogen gas sediment-flux rates, based on all sediment data from all experiments, tended to decrease with increasing sediment chlorophyll a concentrations, although the mesocosm with oysters in Expt 3 did not follow this trend. The decreasing nitrogen gas flux rates indicate a possible nitrogen gas fixation with increasing microphytobenthos biomass. In addition, nitrogen gas flux rates, and thus denitrification, significantly increased with increasing nitrate+nitrite concentrations in the dark and in the light, respectively. 
Table 2. Sediment-flux relationships (after Kemp \& Cornwell 2003)

\begin{tabular}{|c|c|}
\hline Parameter & Definition \\
\hline $\begin{array}{l}\text { Gross oxygen production }\left(\mu \mathrm{mol} \mathrm{m} \mathrm{m}^{-2} \mathrm{~h}^{-2}\right) \\
\text { Nitrogen demand }\left(\mu \mathrm{mol} \mathrm{m} \mathrm{m}^{-2} \mathrm{~h}^{-2}\right) \\
\text { Nitrogen supply }\left(\mu \mathrm{mol} \mathrm{m} \mathrm{m}^{-2} \mathrm{~h}^{-2}\right) \\
\text { Daily flux rate }\left(\mu \mathrm{mol} \mathrm{m} \mathrm{m}^{-2} \mathrm{~h}^{-2}\right)\end{array}$ & $\begin{array}{l}\mathrm{O}_{2} \text { flux rate in light }-\mathrm{O}_{2} \text { flux rate in dark } \\
\text { gross } \mathrm{O}_{2} \text { production } / 6.625 \\
\mathrm{NH}_{4}{ }^{+} \text {flux }+\mathrm{NO}_{3}{ }^{-}+\mathrm{NO}_{2}^{-} \text {flux }+\mathrm{N}_{2}-\mathrm{N} \text { flux (all in light) } \\
\text { (flux rate in light }+ \text { flux rate in dark) } / 2 \times 24\end{array}$ \\
\hline
\end{tabular}

Over our experiments, sources of nitrogen supply, calculated by adding the potential nitrogen sources of ammonium, nitrate + nitrite, and nitrogen gas (Table 2), and based on all sediment data from all experiments, could meet $48 \%$ of our calculated stoichiometric nitrogen demand by the microphytobenthos. With increasing nitrogen demand more of the nitrogen supply was used (Fig. 13b).

Variability was introduced by sequential experiments performed at different seasons, i.e. summer, spring and fall, with each having seasonally different watercolumn nutrient concentrations. For example, in Expt 3, performed in the spring, water-column dissolved inorganic nutrient concentrations were more than twice as high as in Expts 1 and 2. Sediment chlorophyll a levels were more than 3 times as high in Expt 3 as in Expt 2. Oxygen flux rates, strongly dependent on microphytobenthos biomass and particulate organic matter deposition, were about 2 times higher in Expt 3 than in Expt 2. We detected repeated significant differences over all experiments between processes in systems that primarily differed in terms of benthic boundarylayer flow and oysters, despite the temporal variability associated with changing input water.

Our linked mesocosm with realistic water-column turbulence and benthic boundary-layer flow (Porter 1999, Porter et al. 2004) allowed us to include both the water-column and benthic processes and thus their direct and indirect interactions more realistically. Studies addressing individual processes in, for example, benthic boundary-layer devices (Maa et al. 1993, Gust \& Müller 1997, Thomsen \& Flach 1997, Boynton et al. 1981) or water-column devices (e.g. Sullivan et al. 1991) provide detailed information on a certain interaction or process. However, scaling results from studies focused on isolated processes to natural systems has been questioned (Schindler 1998, Haag \& Matschonat 2001). Results of multiple individual interactions combined do not scale up to the ecosystem because of indirect linkages and feedbacks that are not accounted for. Models that use collective data from individual process studies may not be realistic and should include physical and biological processes realistically (e.g. Lee et al. 2002) and should use data obtained from whole-ecosystem studies that include direct and indirect links. Indirect links, such as the processes shifting to the benthic environ- ment in this study, have often only been found when results were unexpected (Sih et al. 1985).

A moderate $\left(0.6 \mathrm{~cm} \mathrm{~s}^{-1}\right)$ bottom shear velocity (in interaction with mat age) eroded and reduced microphytobenthos biomass, and nutrient regeneration to the water column was significantly reduced. Underwood \& Paterson (1993) also found that microphytobenthos biomass was correlated with shear strength and critical shear stress. Microphytobenthos can increase sediment stability (Madsen et al. 1993) through the alteration of adhesive-cohesive bonding among particles, thereby reducing sediment erodibility. However, the age of the microphytobenthos mat can also affect the critical erosional velocities (Madsen et al. 1993, Sutherland et al. 1998). We observed oxygen bubbles in the mat that may have lifted the carpet, facilitating microphytobenthos erosion and leading to mass erosion at a moderate bottom shear of about $0.6 \mathrm{~cm} \mathrm{~s}^{-1}$. Mass erosion of microphytobenthos has also been observed by Miller et al. (1996). Sundbäck \& Joensson (1988) suggested that the interaction of nutrients, light, sediment type, and 'degree of exposure to water movement' determines microphytobenthos biomass. Overall, shear velocity/shear stress must be considered in addition to light availability as it significantly affects microphytobenthos biomass above critical erosional levels. Microphytobenthos biomass affected nutrient flux rates from the sediment and nutrient transformations; however, effects of microphytobenthos, nutrients, and particulate organic matter on coupled nitrification-denitrification are complex (Newell et al. 2002, Risgaard-Petersen 2003).

From the results of our mesocosm study, we suggest that historic oyster abundances in the Chesapeake Bay (Newell 1988) maintained higher light levels at the sediments of the shallow flanks in Chesapeake Bay and thus may have increased microphytobenthos biomass in shallow quiescent parts of Chesapeake Bay with low bottom shear velocities, but not necessarily in areas with moderate to high shear velocities. Although few measurements of bottom shear velocity (shear stress) are available for the Chesapeake Bay, Wright et al. (1997) estimated bottom shear velocities of 1.0 to $1.4 \mathrm{~cm} \mathrm{~s}^{-1}$ for the lower Chesapeake Bay. These values are higher than the moderate bottom shear levels we chose for our experiments. 
An unexpected result of these complex ecosystem experiments was the observation that moderate bottom shear velocity may reduce microphytobenthos biomass and with it the beneficial effects of microphytobenthos mats in shallow-water environments, despite any light available due to oyster feeding. Thus, in addition to any beneficial effects of bivalve feeding on light penetration to the bottom and on microphytobenthos biomass, adverse effects of the erosion and transport of microphytobenthos and biodeposits by bottom shear stress and the transport of microphytobenthos and biodeposits by currents to sites where anaerobic decomposition predominates must be considered. In addition, higher bottom shear velocities than those used in our experiments will induce sediment resuspension, as observed in clam habitats such as Breakwater Harbor, Delaware (Bock \& Miller 1994), or clam habitats in Great South Bay, New York (Bricelj et al. 1984), further affecting water-column turbidities, and thus may also affect microphytobenthos abundance and ecosystem processes; yet few measurements of bottom shear stress are available for natural habitats.

Experiments and models that will aid in prediction of the effects of bivalve suspensions feeders on ecosystems must include realistic physical conditions. It is the interaction of the biological and the physical processes that affects the overall ecosystem processes and water quality. Data used in models must come from experiments that include direct and indirect effects of interactions between biological and physical components of the ecosystem. Controlled whole-ecosystem experiments further varying physical variables (e.g. bottomshear) and varying biological variables (e.g. bivalve species, density, ecological complexity), supplemented with smaller-scale experimental approaches to study specific interactions, are needed to further resolve the complex interactive effects of bivalves and water flow on benthic-pelagic coupling and on overall water quality. This may be done by (1) designing a new generation of mesocosms with both realistic water-column turbulence levels and high bottom shear stress in single systems, and by (2) conducting comparative ecosystem studies with tidal/episodic sediment resuspension and organisms, and using simultaneous rather than sequential replication.

Acknowledgements. We are grateful to R. I. E. Newell for his advice, assistance, and review of an early draft of this manuscript. In addition, we thank T. Wazniak and D. Hinkle for their help with parts of the ecosystem experiments. Many thanks to F. S. Porter for help during the project and for reading several drafts of this manuscript. This research was supported by grant no. R 824850-01-0 from the USEPA STAR program as part of the Multiscale Experimental Ecosystem Research Center (MEERC) at the University of Maryland Center for Environmental Science (UMCES), and by a fellowship of the Horn Point Laboratory to E.T.P. This is UMCES publication no. 3701.

\section{LITERATURE CITED}

Asmus RM, Asmus H (1991) Mussel beds: limiting or promoting phytoplankton? J Exp Mar Biol Ecol 148:215-232

Asmus H, Asmus RM, Prins TC, Dankers N, Frances G, Maass B, Reise K (1992) Benthic-pelagic flux rates on mussel beds-tunnel and tidal flume methodology compared. Helgol Meeresunters 46:341-361

Asmus RM, Jensen MH, Jensen KM, Kristensen E, Asmus H, Wille A (1998) The role of water movement and spatial scaling for measurement of dissolved inorganic nitrogen fluxes in intertidal sediments. Estuar Coast Shelf Sci 46: $221-232$

Bayne BL, Hawkins AJS (1992) Ecological and physiological aspects of herbivory in benthic suspension-feeding molluscs. In: John DM, Hawkins SJ, Price JH (eds) Plantanimal interactions in the marine benthos. Systematics Association Special Vol 46. Clarendon Press, Oxford, p 265-288

Bock M, Miller D (1994) Seston variability and daily growth in Mercenaria mercenaria on an intertidal sandflat. Mar Ecol Prog Ser 114:117-127

Boynton JE (1985) The influence of current velocity on nutrient and oxygen exchanges between estuarine sediments and the water column. PhD thesis, University of Maryland, College Park

Boynton WR, Kemp WM, Osborne CG, Kaumeyer KR, Jenkins MC (1981) Influence of water circulation rate on in situ measurements of benthic community respiration. Mar Biol 65:185-190

Bricelj VM, Malouf RE, Quillfeldt CD (1984) Growth of juvenile Mercenaria mercenaria and the effect of resuspended bottom sediments. Mar Biol 84:167-173

Caffrey JM, Sloth NP, Kaspar HF, Blackburn TH (1993) Effect of organic loading on nitrification and denitrification in a marine sediment microcosm. FEMS Microbiol Ecol 12: 159-167

Chen CC, Petersen JE, Kemp WM (1997) Spatial and temporal scaling of periphyton growth on walls of estuarine mesocosms. Mar Ecol Prog Ser 155:1-15

Chen CC, Petersen JE, Kemp WM (2000) Nutrient-uptake in experimental estuarine ecosystems: scaling and partitioning rates. Mar Ecol Prog Ser 200:103-116

Cloern JE (1982) Does the benthos control phytoplankton biomass in South San Francisco Bay? Mar Ecol Prog Ser 9: 191-202

Cohen RRH, Dresler PV, Philips EJP, Cory RL (1984) The effect of the asiatic clam, Corbicula fluminea, on phytoplankton of the Potomac River, Maryland. Limnol Oceanogr 29:170-180

Crawford SM, Sanford LP (2001) Boundary shear velocities and fluxes in the MEERC experimental ecosystems. Mar Ecol Prog Ser 210:1-12

Dade WB (1993) Near-bed turbulence and hydrodynamic control of diffusional mass transfer at the sea floor. Limnol Oceanogr 38:52-69

Dame RF (1996) Ecology of marine bivalves: an ecosystem approach. CRC Press, Boca Raton, FL

Dame R, Libes S (1993) Oyster reefs and nutrient retention in tidal creeks. J Exp Mar Biol Ecol 171:251-258

Dame R, Zingmark R, Stevenson H, Nelson D (1980) Filter feeder coupling between the estuarine water column and benthic subsystems. In: Kennedy V (ed) Estuarine perspectives. Proc 5th Biennial Int Estuar Res Conf, Jekyll Island, Georgia, October 7-12, 1979. Academic Press, New York, p 521-526

Dame RF, Spurrier JD, Wolaver TG (1989) Carbon, nitrogen 
and phosphorus processing by an oyster reef. Mar Ecol Prog Ser 54:249-256

Dame RF, Dankers N, Prins T, Jongsma H, Smaalt A (1991) The influence of mussel beds on nutrients in the Western Wadden Sea and Eastern Scheldt estuarues. Estuaries 14:130-138

Diaz RJ, Schaffner LC (1990) The functional role of estuarine benthos. In: Haire M, Krome EL (eds) Perspectives on the Chesapeake Bay, 1990, advances in estuarine science. United States Environmental Protection Agency for the Chesapeake Bay Program, Baltimore, p 25-56

Doering PH, Oviatt CA, Kelly JF (1986) The effects of the filter feeding clam Mercenaria mercenaria on carbon cycling in experimental mesocosms. J Mar Res 44:839-861

Enoksson V (1993) Nutrient recycling by coastal sediments: effects of added algal material. Mar Ecol Prog Ser 92: 245-254

Fingerson LM, Freymuth P (1983) Thermal anemometers. In: Goldstein RJ (ed) Fluid mechanics measurements, 2nd edn. Taylor \& Francis, Washington, DC, p 99-153

Fréchette M, Butman CA, Geyer WR (1989) The importance of boundary-layer flows in supplying phytoplankton to the benthic suspension feeder, Mytilus edulis L. Limnol Oceanogr 34:19-36

Gust G (1988) Skin friction probes for field applications. J Geophys Res 93:14 121-14 132

Gust G, Müller V (1997) Interfacial hydrodynamics and entrainment functions of currently used erosion devices. In: Burt N, Parker R, Watts J (eds) Cohesive sediments. John Wiley \& Sons, New York, p 149-174

Haag D, Matschonat G (2001) Limitations of controlled experimental systems as models for natural systems: a conceptual assessment of experimental practices in biogeochemistry and soil science. Sci Total Environ 277:199-216

Haven DS, Morales-Alamo R (1966) Aspects of biodeposition by oysters and other invertebrate filter feeders. Limnol Oceanogr 1:487-498

Haven D, Morales-Alamo R (1970) Filtration of particles from suspension by the American oyster Crassostrea virginica. Biol Bull (Woods Hole) 139:248-264

Hill P (1992) Reconciling aggregation theory with observed vertical fluxes following phytoplankton blooms. J Geophys Res C Oceans 97(C2):2295-2308

Jordan SJ (1987) Sedimentation and remineralization associated with biodeposition by the American oyster Crassostrea virginica (Gmelin). PhD thesis, University of Maryland, College Park

Kana TM, Darkangelo C, Hunt MD, Oldham JB, Bennett GE, Cornwell JC (1994) Membrane inlet mass spectrometer for rapid high-precision determination of $\mathrm{N}_{2}, \mathrm{O}_{2}$ and $\mathrm{Ar}$ in environmental water samples. Analyt Chem 66:4166-4170

Karakassis I, Tsapakis M, Hatziyanni E (1998) Seasonal variability in sediment profiles beneath fish farm cages in the Mediterranean. Mar Ecol Prog Ser 162:243-252

Kemp WM, Cornwell JC (2003) Role of benthic communities in the cycling and balance of nitrogen in Florida Bay. US Environmental Protection Agency, Region 4, Atlanta, GA

Kennedy VS (1996) The ecological role of the eastern oyster, Crassostrea virginica, with remarks on disease. J Shellfish Res 15:177-183

Lee JY, Tett P, Jones K, Jones S, Luyten P, Smith C, WildAllen K (2002) The PROWQM physical-biological model with benthic-pelagic coupling applied to the northern North Sea. J Sea Res 48:287-331

Lorenzen CJ (1967) Determination of chlorophyll and phaeopigments: spectrophotometric equations. Limnol Oceanogr $12: 343-346$
Lund EJ (1957) Self silting, survival of the oyster as a closed system, and reducing tendencies of the environment of the oyster. Publ Inst Mar Sci Univ Tex 4:313-319

Maa JPY, Wright LD, Lee CH, Shannon TW (1993) VIMS sea carousel: a field instrument for studying sediment transport. Mar Geol 115:271-287

Madsen KN, Nilsson P, Sundbäck K (1993) The influence of benthic microalgae on the stability of a subtidal sediment. J Exp Mar Biol Ecol 170:159-177

Miller DC, Geider RJ, MacIntyre HL (1996) Microphytobenthos: the ecological role of the 'Secret Garden' of unvegetated, shallow-water marine habitats. II. Role in sediment stability and shallow-water food webs. Estuaries 19: 202-212

Newell RIE (1988) Ecological changes in Chesapeake Bay: are they the result of overharvesting the American oyster, Crassostrea virginica? In: Lynch MP, Krome EC (eds) Understanding the estuary: advances in Chesapeake Bay research. Chesapeake Research Consortium Publication, 129(CBP/TRS 24/88), Gloucester Point, VA, p 536-546

Newell R, Cornwell JC, Owens M (2002) Influence of simulated bivalve biodeposition and microphytobenthos on sediment nitrogen dynamics. Limnol Oceanogr 47:1367-1379

Officer CB, Smaya TJ, Mann R (1982) Benthic filter feeding: a natural eutrophication control. Mar Ecol Prog Ser 9: 203-210

O'Riordan CA, Monismith SG, Koseff JR (1993) A study of concentration boundary-layer formation over a bed of model bivalves. Limnol Oceanogr 38:1712-1729

Parsons TR, Maita Y, Lalli CM (1984) A manual of chemical and biological methods for seawater analysis. Pergamon, Oxford

Peters F, Redondo J (1997) Turbulence generation and measurement: application to studies on plankton. Sci Mar 61 (Supl 1):205-228

Porter ET (1999) Physical and biological scaling of benthicpelagic coupling in experimental ecosystem studies. $\mathrm{PhD}$ thesis, University of Maryland, College Park

Porter ET, Sanford LP, Suttles SE (2000) Gypsum dissolution is not a universal integrator of 'water motion'. Limnol Oceanogr 45:145-158

Porter ET, Sanford LP, Gust G, Porter FS (2004) Combined water-column mixing and benthic boundary-layer flow in mesocosms: key for realistic benthic-pelagic coupling studies. Mar Ecol Prog Ser 271:43-60

Risgaard-Petersen N (2003) Coupled nitrification-denitrification in autotrophic and heterotrophic estuarine sediments: on the influence of benthic microalgae. Limnol Oceanogr 48: 93-105

Sanford LP (1997) Turbulent mixing in experimental ecosystem studies. Mar Ecol Prog Ser 161:265-293

Sanford LP, Crawford SM (2000). Mass transfer versus kinetic control of uptake across solid-water boundaries. Limnol Oceanogr 45:1180-1186

Santschi P, Hohener P, Benoit G, Buchholtz-ten Brink M (1990) Chemical processes at the sediment-water interface. Mar Chem 30:269-315

Schindler DW (1998) Replication versus realism: the need for ecosystem-scale experiments. Ecosystems 1:323-334

Sih A, Crowley P, Mcpeek M, Petranka J, Strohmeier K (1985) Predation, competition and prey communities: a review of field experiments. Annu Rev Ecol Syst 16:269-311

Steel RGD, Torrie JH (1980) Principles and procedures of statistics: a biometrical approach, 2nd edn. MacGraw-Hill, New York

Sullivan BK, Doering PH, Oviatt CA, Keller AA, Frithsen JB (1991) Interactions with the benthos alter pelagic food web 
structure in coastal waters. Can J Fish Aquat Sci 48: 2276-2284

Sundbäck K, Graneli W (1988) Influence of microphytobenthos on the nutrient flux between sediment and water: a laboratory study. Mar Ecol Prog Ser 43:63-69

Sundbäck K, Joensson B (1988) Microphytobenthic productivity and biomass in sublittoral sediments of a stratified bay, southeastern Kattegat. J Exp Mar Biol Ecol 122:63-81

Sundbäck K, Enoksson V, Graneli W, Pettersson K (1991) Influence of sublittoral microphytobenthos on the oxygen and nutrient flux between sediment and water: a laboratory continuous-flow study. Mar Ecol Prog Ser 74:263-279

Sundbäck K, Miles A, Goransson E (2000) Nitrogen fluxes, denitrification and the role of microphytobenthos in microtidal shallow-water sediments: an annual study. Mar Ecol Prog Ser 200:59-76

Sutherland TF, Grant J, Amos CL (1998) The effect of carbohydrate production by the diatom Nitzschia curvilineata on the erodibility of sediment. Limnol Oceanogr 43:65-72

Swanberg IL (1991) The influence of the filter-feeding bivalve Cerastoderma edule L. on microphytobenthos: a laboratory study. J Exp Mar Biol Ecol 151:93-111

Taghon GL, Greene RR (1992) Utilization of deposited and suspended particulate matter by benthic 'interface' feeders. Limnol Oceanogr 37:1370-1391

Tennekes H, Lumley JL (1972) A first course in turbulence, 15th edn. MIT Press, Cambridge, MA

Thomsen L, Flach E (1997) Mesocosm observations of fluxes of particulate matter within the benthic boundary layer. J Sea Res 37:67-79

Underwood GJC, Paterson DM (1993) Seasonal changes in diatom biomass, sediment stability and biogenic stabilization in the Severn Estuary. J Mar Biol Assoc UK 73:871-887

Van Heukelem L, Lewitus AJ, Kana TM, Craft NE (1992) High-performance liquid-chromatography of phyto-

Editorial responsibility: Otto Kinne (Editor), Oldendorf/Luhe, Germany plankton pigments using a polymeric reversed-phase C-18 column. J Phycol 28:867-872

Van Heukelem L, Lewitus J, Kana TM, Craft NE (1994) Improved separations of phytoplankton pigments using temperature-controlled high-performance liquid-chromatography. Mar Ecol Prog Ser 114:303-313

Verwey J (1952) On the ecology of distribution of cockle and mussel in the Dutch Waddensea Sea, their rôle in sedimentation and the source of their food supply. Arch Néerl Zool 10:217-239

Ward JE, Sanford LP, Newell RIE, MacDonald BA (1998) A new explanation of particle capture in suspension-feeding bivalve molluscs. Limnol Oceanogr 43: 741-752

Widdows J, Brinsley MD, Bowley N, Barrett C (1998) Use of annular flumes to determine the influence of current velocity and bivalves on material flux at the sedimentwater interface. Estuaries 21:552-559

Wildish D, Kristmanson D (1997) Benthic suspension feeders and flow. Cambridge University Press, Cambridge, UK

Wright LD, Schaffner LC, Maa JPY (1997) Biological mediation of bottom boundary layer processes and sediment suspension in the lower Chesapeake Bay. Mar Geol 141: $27-50$

Wright RT, Coffin RB, Ersing CP, Pearson D (1982) Field and laboratory measurements of bivalve filtration of natural marine bacterioplankton. Limnol Oceanogr 27:91-98

Yallop ML, de Winder B, Paterson DM, Stal LJ (1994) Comparative structure, primary production and biogenic stabilization of cohesive and non-cohesive marine sediments inhabited by microphytobenthos. Estuar Coast Shelf Sci 39:565-582

Zimmermann C, Price M, Montgomery J (1977) Operation, methods, and quality control of Technicon AutoAnalyzer II systems for nutrient determination in seawater. Harbor Branch Foundation, Fort Pierce, FL

Submitted: May 6, 2003; Accepted: November 18, 2003 Proofs received from author(s): April 15, 2004 